\title{
Hubungan antara Aktivitas Fisik dan Aktivitas Sedentari dengan Status Gizi Lebih pada Anak Sekolah Dasar
}

\section{Relationship between Physical Activity, Sedentary Activity and Overnutrition Status among Elementary School Student}

\author{
Erlina Nurlaili Rahma*, Bambang Wirjatmadi
}

\begin{abstract}
ABSTRAK
Latar Belakang: Status Gizi Lebih disebabkan oleh multifaktor yaitu faktor perilaku seperti kebiasaan makan, aktivitas fisik, aktivitas sedentari, dan faktor genetik.

Tujuan: Menganalisis hubungan antara aktivitas fisik serta aktivitas sedentari dengan status gizi lebih pada anak usia sekolah dasar.

Metode: Penelitian ini menggunakan desain case control, dengan sampel 22 anak kelompok status gizi lebih dan 22 anak kelompok status gizi normal. Simple random sampling merupakan metode yang digunakan dalam pengambilan sampel. Pengumpulan data menggunakan metode wawancara langsung dengan bantuan kuesioner PAQ-C (Physical Activity Questionnare-Children) untuk mencatat aktivitas fisik, dan kuesioner ASAQ (Adolescent Sedentari Activity Questionnaire) untuk mencatat aktivitas sedentari. Data dianalisis dengan uji statistik Chi-Square untuk aktivitas fisik dan Spearman untuk aktivitas sedentari.

Hasil: Hasil penelitian menunjukkan bahwa terdapat hubungan yang signifikan antara aktivitas fisik dengan status gizi lebih ( p 0,016) didapatkan nilai $\mathrm{OR}=0,218$ dengan $\mathrm{Cl} 95 \%(0,061-0,775)$ dapat diartikan bahwa siswa yang melakukan aktivitas fisik dengan kategori baik beresiko 0,218 kali lebih kecil mengalami status gizi lebih. Sedangkan, untuk aktivitas sedentari $(p=0,026)$ dengan nilai $\mathrm{OR}=4,5$ dan $\mathrm{Cl} 95 \%(1,145-17,679)$ artinya siswa yang melakukan aktivitas sedentari $>5$ jam maka memiliki kecenderungan 4,5 kali lebih besar untuk mengalami status gizi lebih dibandingkan dengan siswa yang melakukan aktivitas sedentari $<2$ jam.

Kesimpulan: Rendahnya aktivitas fisik dan tingginya aktivitas sedentari pada anak sekolah dasar berhubungan dengan masalah status gizi lebih. Siswa dengan status gizi lebih sebaiknya melakukan aktivitas fisik lebih banyak lagi, dan mengurangi kegiatan yang kurang gerak.
\end{abstract}

Kata kunci: Aktivitas fisik, aktivitas sedentari, status gizi lebih

\section{ABSTRACT}

Background: Overnutrition status can be influenced by multifactor such as behaviors are eating habits, physical activity, sedentary activity, and genetic.

Objectives: Analyze the relationship between of physical activity and sedentary activity with overnutrition status of elementary students.

Methods: The study using a case control design, with respondents were 22 students in overnutrition status group and 22 students in normalnutrition status group. Simple random sampling was used this study. Data were collected throught direct interview using Physical Activity Questionnare-Children (PAQ-C) to record respondent's physical activity, and Adolescent Sedentari Activity Questionnaire (ASAQ) to record respondent's sedentary activity. Analysis data using Chi-Square test for physical activity and Spearman test for physical activity.

Results: The result showed that there was a relationship between physical activity with overnutrition status $(p=0.016)$ and an $O R=0.218$ with $\mathrm{Cl} 95 \%$ (0.061 - 0.775) which mean that student who did physical activity with good category at risk 0.218 times less to be overnutition status. As for sedentary activity $(p=0.026)$ with OR=5.5 and Cl 95\% (1.145-17.679), which mean students who did sedentary activity more than 5 hour at risk 4.5 times greater than to be overnutrition status compared with students who did physical activity less than 2 hour.

Conclusion: The low of physical activity and high of sedentary activityin elementary students were related with overnutrition status. Student with overnutrition status must be increase physical activity and reduced sedentary activity.

Keywords: physical activity, sedentary activity, overnutrition status 


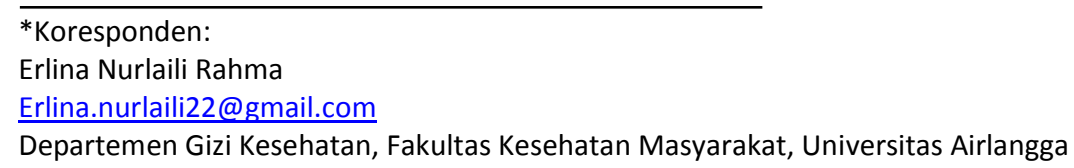

\section{PENDAHULUAN}

Obesitas merupakan akumulasi lemak yang tidak normal sehingga dapat meningkatkan peluang terjadinya beberapa resiko kesehatan seperti penyakit degeneratif pada seorang individu. Obesitas menjadi suatu epidemik global di seluruh dunia tidak hanya terjadi pada warga di negara maju, tetapi juga terjadi pada warga di negara berkembang, sehingga menjadi salah satu masalah kesehatan yang di prioritaskan dan harus segera ditangani ${ }^{1}$. Jumlah prevalensi individu yang mengalami status gizi lebih (overweight dan obesitas) saat ini telah terbukti mencapai pada tingkat membahayakan hal tersebut dibuktikan dengan peningkatan angka prevalensi kasus status gizi lebih (obesitas dan gizi lebih) yang sangat tajam pada seluruh kalangan tidak hanya dewasa saja, namun juga pada usia muda yaitu anakanak di seluruh dunia. Berdasarkan data dari National Health and Nutrition Examination Survey (NHANES) prevalensi obesitas pada anak-anak (6-11 tahun) di tahun 2007-2008 sebesar 16,8\% meningkat menjadi $18,5 \%$ di tahun $2015-2016^{2}$. Berdasarkan data obesity update tahun 2017, angka prevalensi obesitas pada anak laki-laki dengan usia pertumbuhan yaitu 3-17 tahun di United States sebesar 20\%, sedangkan untuk anak perempuan dengan usia 3-17 tahun sebesar $18 \%^{3}$.

Hasil penelitian yang dilakukan secara global pada tahun 2013 didapatkan hasil yaitu sebanyak 42 juta anak mengalami kelebihan berat badan pada usia dibawah lima tahun, angka tersebut diantaranya 31 juta anak berada di negara berkembang, sedangkan 11 juta anak berada pada negara maju ${ }^{4}$. Menurut data RISKESDAS (Riset Kesehatan Dasar) pada tahun 2013 menunjukan bahwa di Indonesia anak yang berusia 5-12 tahun yang mengalami kegemukan angka prevalensinya relatif masih tinggi yaitu sebesar $18,8 \%$ diantaranya prevalensi anak gemuk sebesar $10,8 \%$, sedangkan anak sangat gemuk sebesar $8 \%{ }^{5}$. Provinsi Jawa timur merupakan salah satu daerah diantara daerah lainnya di Indonesia yang anak usia 5-12 tahun mengalami obesitas angkanya melebihi angka prevalensi nasional yaitu sebesar 19,3\%. Pada anak perempuan prevalensinya lebih tinggi dibandingkan dengan anak laki-laki masingmasing yaitu $18,3 \%$ dan $10,5 \%{ }^{5}$. Prevalensi gizi lebih (overweight) dan obesitas di Surabaya melebihi angka nasional dan Jawa Timur yaitu sebesar $22,2 \%^{5}$.

Status Gizi Lebih disebabkan karena multifaktor yaitu dikarenakan faktor perilaku (kebiasaan makan, aktivitas fisik, dan aktivitas sedentari) serta faktor genetik berpengaruh terhadap status gizi lebih, kondisi lingkungan, keadaan ekonomi, dan faktor budaya mendukung keduanya ${ }^{6}$. Obesitas dan Aktivitas fisik terdapat kaitan yang erat dimana keduanya berhubungan dengan penumpukan lemak tubuh akibat dari ketidakseimbangan antara total pengeluaran energi dengan total masukan asupan energi yang terjadi dalam tubuh $^{7}$. Tingginya asupan energi dan zat gizi merupakan output dari konsumsi makanaan yang berlebihan, sedangkan rendahnya energi yang dikeluarkan merupakan output dari kurangnya aktivitas fisik ditandai dengan minimnya olahraga ${ }^{8}$.

Gaya hidup saat ini mengalami banyak perubahan diantaranya yaitu gaya hidup tradisional yang tergeser dengan gaya hidup sedentari sehingga menyebabkan resiko terjadinya status gizi lebih semakin meningkat. Anak usia sekolah cenderung lebih memilih aktivitas sedentari seperti bermain komputer, bermain smartphone, dan menonton televisi. Melakukan aktivitas sedentari yang terlalu lama mengakibatkan ketidakseimbangan energi, hal tersebut dikarenakan masukan energi dalam tubuh lebih besar dibandingkan dengan keluaran energi energi sehingga berdampak pada status gizi lebih atau obesitas ${ }^{7}$.

Tujuan dalam penelitian ini yaitu untuk mengetahui analisis hubungan antara aktivitas fisik dan aktivitas sedentari dengan status gizi lebih pada anak usia sekolah dasar di SD Negeri Ploso I-172 Surabaya. Lokasi ini dipilih karena berdasarkan penelitian Yaqin menunjukan bahwa prevalensi gizi lebihdan obesitas pada anak siswa SDN Ploso I-172 Surabaya sebesar 20\%, diantaranya $18 \%$ overweight dan $2 \%$ obesitas $^{9}$.

\section{METODE}

Desain penelitian yang digunakan dalam study ini yaitu desain kasus kontrol (case control). Penelitian ini mengambil populasi seluruh siswa-siswi kelas 4 dan 5 di Sekolah Dasar Negeri Ploso I-172 Tambaksari Kota Surabaya dengan siswa kelas 4 sejumlah 101 anak, sedangkan pada kelas 5 sejumlah 109 anak, sehingga total populasi penelitian sebesar 210 siswa. Penelitian ini menggunakan desain kasus kontrol yaitu membandingkan antara kelompok kasus dengan kelompok kontsrol, maka dilakukan pengelompokkan sampel yaitu responden yang mempunyai masalah status gizi lebih (Obesitas dan overweight) termasuk dalam kelompok kasus, sedangkan responden yang tidak mempunyai masalah status gizi atau dengan status gizi normal masuk dalam kelompok kontrol Pengambilan data dilakukan pada bulan mei tahun 2019. Teknik simple random sampling merupakan teknik yang dipilih dalah pengambilan sampel pada penelitian ini. Sampel minimal yang dibutuhkan sebesar 44 sampel diantaranya 22 sempel kelompok kasus, 22 sampel kelompok kontrol. Dalam perhitungan sampel ini diambil nilai proporsi sebesar $P=0,26$, dengan nilai $O R=5,15^{10}$.

Instrumen yang digunakan adalah formulir biodata responden, kuesioner PAQ-C (Physical Activity Questionnaire-Children), kuesioner ASAQ (Adolescent Sedentari Activity Questionnaire), dan kuesioner pengetahuan gizi. Formulir biodata responden digunakan untuk mencatat nama dan tanggal lahir. Kuesioner PAQ-C (Physical Activity QuestionnaireChildren) digunakan untuk mencatat aktivitas fisik 
responden pada tujuh hari terakhir ${ }^{11}$. Dalam kuesioner ini terdiri dari 10 pertanyaan dan pada masing-masing pertanyaan terdapat 5 opsi jawaban. Cara penilaian dalam kuesioner ini yaitu jawaban A dikali 1, jawaban B dikali 2, jawaban $C$ dikali 3, jawaban D dikali 4, jawaban $E$ dikali 5, kemudian dijumlahkan jawaban A, B, C, D, dan E. hasil tersebut akan digunakan sebagai hasil nilai PAQ-C setiap responden. Setelah itu dicari median dari total PAQ-C yang nantinya akan menjadi standar PAQ- $\mathrm{C}^{11}$. Hasil median dari total PAQ-C setiap responden pada penelitian ini yaitu 60,5 . Sehingga menggunakan data nominal < median $(60,5)$ dan $\geq$ median $(60,5)$.

Kuesioner ASAQ (Adolescent Sedentari Activity Questionnaire) digunakan untuk mencatat semua aktivitas sedentari responden selama satu minggu terakhir, diantaranya 5 hari efektif dan 2 hari libur sekolah. Siswa diberikan daftar kegiatan yang nantinya akan diisi jumlah menit dalam melakukan kegiatan tersebut $^{12}$. Hasil kuesioner tersebut nantinya akan dijumlah total aktivitas sedentari dalam 7 hari kemudian dirata-rata dalam satu hari, kemudian diklasifikasikan menjadi Rendah (<2 Jam/hari), Sedang (2-5 Jam/hari), dan Tinggi (> $5 \mathrm{Jam} /$ hari $^{13}$. Kuesioner pengetahuan gizi terdiri dari 15 pertanyaan dengan pilihan jawaban benar dan salah. Skor jawaban benar kemudian diklasifikasikan menjadi baik (skor benar 76-100\%), sedang (skor benar $56-75 \%$ ), dan kurang (skor benar $<56 \%$ ). Penelitian ini merupakan penelitian case control, maka dilakukan skrining awal dengan melakukan penimbangan berat badan menggunakan timbangan digital GEA yang mempunyai spesifikasi diantaranya memiliki ketahanan sampai dengan $150 \mathrm{~kg}$. Selain itu juga dilakukan pengukuran tinggi badan responden dengan alat Microtoise merk GEA dengan spesifikasi anatara lain alat ditempel di tembok dan memiliki panjang maksimal 200 $\mathrm{cm}$. Pengukuran status gizi pada skrining awal dilakukan oleh enumerator yaitu mahasiswa gizi semester 8 . Status gizi anak diklasifikasi menggunakan indikator Z-Score yaitu obesitas (>2 Standar Deviasi), overweight (>1 SD sampai 2 Standar Deviasi), normal (-2 Standar Deviasi sampai 1 Standar Deviasi), kurus (-3 Standar Deviasi sampai -2 Standar Deviasi), dan sangat kurus $(<-3$ Standar Deviasi). Setelah mendapatkan data, analisis dilakukan menggunaan uji statistik Chi-Square untuk menguji data dengan skala data nominal yaitu variabel aktivitas fisik dan status gizi lebih, sedangkan Spearman digunakan untuk skala data ordinal yang mempunyai distribusi tidak normal yaitu variabel aktivitas sedentari.

\section{HASIL DAN PEMBAHASAN Karakteristik Responden}

Karakteristik siswa-siswi di Sekolah Dasar Negeri Ploso I-172 Kecamatan Tambaksari Kota Surabaya Tahun 2019 diantaranya usia, jenis kelamin, dan pengetahuan gizi. Pada kelompok status gizi lebih ataupun status gizi normal sebagian besar responden berusia 11 tahun, pernyataan tersebut dapat diambil dari data tabel 1 . Pada anak usia 8-11 tahun mempunyai nafsu makan yang cenderung meningkat sebagai cadangan menuju usia remaja ${ }^{14}$. Berdasarkan tabel 1 pada kelompok status gizi normal sebesar $54,5 \%$ memiliki jenis kelamin lakilaki. Didapatkan hasil yang sama juga pada kelompok status gizi lebih sebagian besar memiliki jenis kelamin laki-laki yaitu sebesar $81,8 \%$. Pada penelitian ini sebagian besar kejadian status gizi lebih terjadi pada anak laki-laki. Hal ini disebabkan karena pertumbuhan anak laki-laki cenderung lebih meningkat dibandingkan dengan anak perempuan ${ }^{15}$. Anak yang mempunyai kecenderungan mengonsumsi energi, protein, karbohidrat, dan lemak lebih besar yaitu pada anak laki-laki, sehingga dapat meningkatkan kontribusi terhadap kejadian status gizi lebih ${ }^{16}$.

Pengetahuan gizi responden dinilai dengan pengisian kuesioner siswa yang berisikan beberapa pertanyaan yang dapat dijawab responden dengan memilih antara jawaban salah dan benar. Dari penelitian menunjukan hasil responden pada keolompok kontrol mayoritas tingkat pengetahuannya dalam kategori sedang yaitu $45,5 \%$, sedangkan pada kelompok kontrol mayoritas tingkat pengetahuannya dalam kategori baik yaitu $59,1 \%$. Hal ini menunjukan bahwa walaupun siswa mempunyai tingkat pengetahuan yang baik, tetapi sebagian besar tidak mengaplikasikan pengetahuan mereka, melainkan masih banyak dari mereka yang mempunyai perilaku makan yang tidak sehat

Tabel 1. Distribusi Karakteristik Siswa-siswi di SD Negeri Ploso I-172 Kecamatan Tambaksari Kota Surabaya Tahun 2019

\begin{tabular}{lcccc}
\hline \multicolumn{1}{c}{ Karakteristik Responden } & \multicolumn{2}{c}{ Status Gizi Normal } & Status Gizi Lebih \\
\cline { 2 - 5 } & $\mathbf{n}$ & \% & $\mathbf{n}$ & \% \\
\hline Jenis Kelamin & 10 & 45,5 & 4 & 18,2 \\
Perempuan & 12 & 54,5 & 18 & 81,8 \\
Laki-laki & & & & \\
\hline Umur & 8 & 36,4 & 9 & 40,9 \\
10 Tahun & 14 & 63,6 & 13 & 59,1 \\
11 Tahun & & & & 0 \\
\hline Pengetahuan Gizi & 3 & 13,6 & 9 & 40,9 \\
Rendah & 10 & 45,5 & 13 & 59,1 \\
Sedang & 9 & 40,9 & & \\
Baik & & & & \\
\end{tabular}

\section{Aktivitas Fisik}

Aktivitas fisik dalam penelitian diklasifikasikan dalam dua kategori yaitu kategori baik dan kategori rendah. Diperlukan peningkatan aktivitas fisik oleh tubuh untuk menjaga metabolism basal tubuh agar tidak turun dan tidak menjadi surplus energi yang dapat mengakibatkan gizi lebih ${ }^{17}$. Berdasarkan data tabel 2 dapat dijelaskan bahwa pada kelompok status gizi 
normalmayoritas aktivitas fisiknya pada kategori baik sebesar $68,2 \%$. Sedangkan, pada responden dengan status gizi lebih mayoritas mempunyai aktivitasnya rendah yaitu sebesar 68,2\%. Hasil uji statistik menggunakan uji statistic Chi-Square didapatkan nilai $p$ $0,016<0,05$ menunjukkan bahwa terdapat hubungan antara aktivitas fisik dengan status gizi lebih di SD Negeri Ploso I-172 Tambaksari Kota Surabaya. Didapatkan nilai $\mathrm{OR}=0,218$ dengan $\mathrm{Cl} 95 \%(0,061-0,775)$ dapat diartikan bahwa siswa yang melakukan aktivitas fisik bedengan kategori baik resiko 0,218 kali lebih kecil mengalami status gizi lebih.

Hasil tersebut sejalan dengan penelitian yang mendapatkan hasil bahwa anak yang mempunyai aktivitas fisik kurang aktif maka akan meningkatkan berat badan $^{18}$. Berdasarkan penelitian ini siswa yang melakukan aktivitas fisik dengan kategori rendah maka 0,218 kali lebih besar berisiko mengalami status gizi lebih daripada siswa yang melakukan aktivitas fisik dengan kategori tinggi. Menurut penelitian Bhuiyan dkk (2013) menyatakan bahwa resiko 3 kali lebih besar mengalami kelebihan berat badan terjadi pada anak yang melakukan aktivitas fisik <30 menit per hari ${ }^{19}$. Selain itu, berdasarkan penelitian Zamzani dkk (2016) menyatakan bahwa anak beraktivitas fisik $\leq 1$ jam per hari 5 kali lebih besar beresiko untuk mengalami obesitas daripada anak yang beraktivitas fisik $>1$ jam per hari ${ }^{3}$.

Hasil dalam penelitian ini juga sejalan dengan study yang dilakukan pada anak Sekolah Dasar di Palembang tahun 2011 yang menunjukan terdapat hubungan antara aktivitas fisik dengan obesitas. Anak pada kelompok yang beraktivitas fisik ringan atau sedang mempunyai kecenderungan mengalami obesitas 2,4 kali dibandingkan anak pada kelompok yang beraktivitas fisik berat $^{20}$. Hasil penelitian lain juga menunjukan bahwa aktivitas fisik yang rendah berhubungan erat dengan cadangan lemak seorang individu ${ }^{21}$.

Penelitian ini mendapatkan hasil yang sejalan dengan hipotesis dan teori bahwa aktivitas fisik mempunyai hubungan dengan status gizi lebih. Hubungan dalam hal ini yaitu berkaitan dengan penimbunan lemak dalam tubuh dipengaruhi secara

Tabel 2 Distribusi Aktivitas Fisik dan Aktivitas Sedentari pada Siswa-siswi di SDN Ploso I-172 Tambaksari Kota Surabaya Tahun 2019

\begin{tabular}{|c|c|c|c|c|c|c|}
\hline \multirow[t]{2}{*}{ Variabel } & \multicolumn{2}{|c|}{$\begin{array}{c}\text { Status Gizi Normal } \\
(66,6 \text { skor } \pm 11,7)\end{array}$} & \multicolumn{2}{|c|}{$\begin{array}{c}\text { Status Gizi Lebih } \\
(59,09 \text { skor } \pm 13,31)\end{array}$} & \multirow[t]{2}{*}{ P value } & \multirow{2}{*}{$\begin{array}{c}\text { OR } \\
(95 \% \mathrm{CI})\end{array}$} \\
\hline & $n$ & $\%$ & $n$ & $\%$ & & \\
\hline \multicolumn{7}{|l|}{ Aktivitas Fisik } \\
\hline Rendah $(<60,5)$ & 7 & 31,8 & 15 & 68,2 & 0,016 & 0,218 \\
\hline Baik $(>60,5)$ & 15 & 68,2 & 7 & 31,8 & & $(0,061-0,775)$ \\
\hline Total & 22 & 100 & 22 & 100 & & \\
\hline \multicolumn{7}{|l|}{ Aktivitas Sedentari } \\
\hline Rendah (< 2 Jam/hari) & 0 & 0 & 0 & 0 & & \\
\hline Sedang (2-5 Jam/hari) & 13 & 59,1 & 6 & 27,3 & 0,026 & 4,500 \\
\hline Tinggi (> 5 Jam/hari) & 9 & 40,9 & 16 & 72,7 & & $(1,145-17,679)$ \\
\hline Total & 22 & 100 & 22 & 100 & & \\
\hline
\end{tabular}

Berdasarkan data pada tabel 2, dapat dijelaskan bahwa mayoritas responden pada kelompok kontrol (status gizi normal) mempunyai aktivitas sedentari pada kategori sedang (2-5 jam) yaitu sebesar $59,1 \%$. langsung oleh total masukan energi dan total pengeluaran energi. Ketika seseorang melakukan aktivitas fisik yang cukup seperti olahraga maka akan mengurangi simpanan lemak dalam tubuh, sehingga menurunkan resiko mengalami kelebihan berat badan ${ }^{22}$.

Gaya hidup yang berubah mengakibatkan pola makan yang ikut berubah, perubahan tersebut dapat dilihat dari kecenderungan memilih makanan tinggi kalori dan lemak, namun tidak diimbangi dengan beraktivitas fisik yang cukup, sehingga menyebabkan timbulnya masalah gizi diantaranya obesitas. Anak yang aktif melakukan aktivitas diluar rumah akan berpengaruh pada status gizinya, sehingga dapat mengurangi resiko timbulnya masalah gizi lebih. Hal ini disebabkan karena energi dapat dikeluarkan dengan baik sehingga tidak terjadi kelebihan energi yang nantinya berdampak pada penimbunan lemak ${ }^{7}$.

Pada penelitian ini mayoritas responden pada kelompok kasus (status gizi lebih) mempunyai aktivitas fisik kurang, sedangkan kelompok kontrol (status gizi normal) mempunyai aktivitas fisik baik. Hal tersebut dikarenakan, responden dengan kelompok status gizi lebih sebagian menghabiskan waktu istirahat dengan duduk dan jarang melakukan olahraga, tari, atau permainan yang aktif. Sedangkan, pada kelompok status gizi normal sebagian besar menghabiskan waktu istirahat untuk bermain berkeliling atau sedikit berlari.

\section{Aktivitas Sedentari}

Aktivitas sedentari dapat dilihat dari berbagai segi yang mencangkup di tempat bekerja ataupun sekolah. Makna dari perilaku sedentari berbeda dengan kurangnya aktivitas fisik atau tidak berolahraga, akan tetapi sedentari merupakan segala aktivitas yang dilakukan saat selain pada waktu tidur, dimana posisi yang paling dominan adalah duduk dan berbaring sehingga pengeluran energi terlalu sedikit ${ }^{23}$. Dalam penelitian ini aktivitas sedentari diklasifikasikan menjadi 3 kategori diantaranya rendah, sedang, dan tinggi. Hasil pengkategorian tersebut didapatkan dari jumlah ratarata waktu sedentari dalam 7 hari.

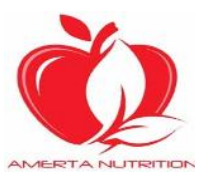


nilai $p$-value $=0,026(p>0,05)$ yang berarti terdapat hubungan antara aktivitas sedentari dengan status gizi lebih. Sedangkan, nilai OR = 4,5 dan Cl 95\% (1,145-17, 679) yang mempunyai arti bahwa siswa yang melakukan aktivitas sedentari > 5 jam maka memiliki kecenderungan 4,5 kali lebih besar untuk mengalami status gizi lebih dibandingkan dengan siswa yang melakukan aktivitas sedentary $<2$ jam.

Berdasarkan tabel 3 aktivitas sedentari terendah yaitu menggunakan komputer untuk keperluan tugas dan membuat kerajinan tangan masing-masing mempunyai mean 0 menit/hari dan standar deviasi 0 menit/hari pada kelompok status gizi lebih ataupun kelompok status gizi normal. Sedangkan, aktivitas sedentari tertinggi pada kelompok status gizi lebih atau normal yaitu menonton televisi dengan nilai mean masing-masing 214,5 menit/hari dengan standar deviasi 29 menit/hari dan 145,5 menit/hari dengan standar deviasi 55,2 menit/hari.

Tabel 3 Mean dan Standar Deviasi Aktivitas Sedentari pada Siswa-siswi di SDN Ploso I-172 Tambaksari Kota Surabaya Tahun 2019

\begin{tabular}{lcccc}
\hline \multicolumn{1}{c}{ Aktivitas Sedentari } & \multicolumn{2}{c}{ Status Gizi Normal } & \multicolumn{2}{c}{ Status Gizi Lebih } \\
\cline { 2 - 5 } & $\begin{array}{c}\text { Mean } \\
\text { (menit/hari) }\end{array}$ & $\begin{array}{c}\text { SD } \\
\text { (menit/hari) }\end{array}$ & $\begin{array}{c}\text { Mean } \\
\text { (menit/hari) }\end{array}$ & $\begin{array}{c}\text { SD } \\
\text { (menit/hari) }\end{array}$ \\
\hline Menonton Televisi & 145,5 & 55,2 & 214,5 & 29 \\
Menonton Film/DVD/Vidio & 53,6 & 17,4 & 74,5 & 19,6 \\
Menggunakan Komputer sebagai hiburan & 19,09 & 8,4 & 75,4 & 21,3 \\
Menggunakan komputer untuk keperluan tugas & 0 & 0 & 0 & 0 \\
Mengerjakan tugas tidak menggunakan komputer & 22,5 & 7,8 & 101 & 20,5 \\
Membaca buku & 47,7 & 15,7 & 54 & 12,9 \\
Melakukan Kursus/les & 60 & 21,2 & 107,3 & 9,8 \\
Duduk di mobil/bus/kereta & 26,4 & 8,9 & 27,2 & 7,6 \\
Membuat kerajinan tangan & 0 & 0 & 0 & 0 \\
Duduk sambil bermain HP & 64,7 & 28,1 & 110,9 & 14,7 \\
Bermain alat music & 34 & 10,1 & 64 & 10,5 \\
\hline
\end{tabular}

Aktivitas sedentari memberikan dampak peningkatan jumlah penduduk yang melakukan pekerjaan fisik dengan sangat terbatas, sehingga kejadian obesitas juga ikut mengalami peningkatan ${ }^{23}$. Kemajuan teknologi seperti halnya televisi, computer dan internet akan mengakibatkan anak menjadi malas bergerak. Faktor resiko terhadap kejadian obesitas pada anak-anak sekolah dasar salah satunya yaitu perilaku sedentari ${ }^{24}$. Akibat dalam menonton televisi menggunakan alat elektronik lebih dari 1 jam setiap hari dapat berkontribusi terhadap obesitas pada anak ${ }^{25}$. Pendapat tersebut juga diperkuat lagi dengan penelitian dimana anak yang menggunakan sebagian besar waktunya melakukan aktivitas sehari-hari dengan posisi berbaring atau duduk contohnya membaca, melihat televisi, mengerjakan tugas sekolah, bermain games, mengaplikasikan gadget atau hanya sekedar bersantai untuk menghabiskan waktu, maka akan meningkatkan resiko mengalami status gizi lebih (obesitas dan overweight). Tidak hanya pada saat weekdays, akan tetapi juga pada waktu weekend dapat menghabiskan waktu 10-12 jam dengan melakukan kegiatan dengan posisi duduk dan berbaring,

Pada anak perilaku sedentarian merupakan faktor resiko yang kuat untuk menyebabkan anak mengalami kegemukan dan obesitas. Perubahan gaya hidup yang sedikit bergerak merupakan penyebab dari masalah penumpukan lemak dalam tubuh, karena tidak ada aktivitas fisik untuk mengeluarkan simpanan lemak yang berlebihan sebagai keluaran energi. Apabila kondisi ini terjadi secara terus-menerus makan dapat menyebabkan kondisi yang lebih buruk lagi ${ }^{26}$.

Penelitian ini mempunyai kelebihan dan kekurangan. Kelebihan dalam penelitian ini yaitu menggunakan instrument $\mathrm{PAQ}-\mathrm{C}$ yang terdiri dari beberapa pertanyaan tentang aktvitas fisik responden. Kelemahan dalam penelitian ini yaitu pada saat dilakukan wawancara aktivitas sedentari ada diantara responden yang lupa durasi kegiatan yang tercatat pada kuesioner ASAQ (Adolescent Sedentari Activity Questionnaire) dalam satu minggu terakhir, sehingga dapat dijadikan masukan untuk penelitian selanjutnya sebaiknya wawancara tidak dilakukan dalam waktu satu hari.

\section{KESIMPULAN}

Ada hubungan yang signifikan antara aktivitas fisik dan aktivitas sedentari dengan status gizi lebih pada anak usia sekolah dasar di SDNegeri Ploso I-172 Tambaksari Kota Surabaya. Responden disarankan untuk memperbanyak aktivitas fisik dengan melakukan olahraga, berlari, atau melakukan permainan yang aktif diwaktu istirahat.

\section{ACKNOWLEDGEMENT}

Peneliti mengucapkan terimakasih kepada SDNegeri Ploso I-172 Tambaksari Kota Surabaya yang telah memberikan izin sehingga dapat melaksanakan penelitian ini sampai selesai, siswa-siswi kelas 4 dan 5 SDN Ploso I-172 Tambaksari Kota Surabaya, serta kawan seperjuangan yang turut membantu dalam pelaksanaan penelitian ini. 


\section{REFERENSI}

1. Rahman Usep Basuki, Handoyo, P. R. Hubungan Obesitas Dengan Risiko Obstructive Sleep Apnea (OSA) Pada Remaja. J. IIm. Kesehat. Keperawatan 8, 44-56 (2012).

2. Devito, N. J., French, L. \& Goldacre, B. Trends in Obesity and Severe Obesity Prevalence in US Youth and Adults by Sex and Age , 2007-2008 to 2015-2016. Am. Med. Assoc. 319, 1723-1725 (2018).

3. M Zamzani, Hamam Hadi, D. A. Aktivitas fisik berhubungan dengan kejadian obesitas pada anak sekolah dasar. J. Gizi dan Diet. 4, 123-128 (2016).

4. Izabel Cristina da Silva Vargas, Rosely Sichieri, Gilza Sandre-Pereira, G. V. da V. Evaluation of an obesity prevention program in. Rev Saude Publica 45, 1-9 (2011).

5. Kemenkes. Riset Kesehatan Dasar. (2013).

6. Enza Sidoti, P. \& Mangiaracina, Gabriele Paolini, G. T. Body Mass Index, family lifestyle, physical activity and eating behavior on a sample of primary school students in a small town of Western Sicily. Ital. J. Public Health 6, 205-217 (2009).

7. Setyoadi, Ika Setyo Rini, T. N. Hubungan Penggunaan Waktu Perilaku Kurang Gerak (Sedentary Behaviour) Dengan Obesitas Pada Anak Usia 9-11 Tahun Di Sd Negeri Beji 02 Kabupaten Tulungagung. J. IImu Keperawatan 3, 155-167 (2015).

8. Dina D'Addesa, Laura D'Addezio, Deborah Martone, Laura Censi, Alessandra Scanu, Giulia Cairella, Amedeo Spagnolo, and ettore M. Dietary Intake and Physical Activity of Normal Weight and Overweight / Obese Adolescents. Int. J. Pediatr. 36, 9 (2010).

9. Mochamad Khusnul Yaqin, F. N. Prevalensi Obesitas Pada Anak Usia Sd Menurut Imt/U Di Sd Negeri Ploso II No 173 Surabaya. J. Pendidik. Olahraga dan Kesehat. 02, 114-118 (2014).

10. Rumida. Pengaruh Perilaku Makan dan Aktivitas Fisik Terhadap Kejadian Obesitas Pada Pelajar di SMU Methodist Medan. Wahana Inov. 3, 6-13 (2014).

11. Kowalski, K. C. \& Ph, D. The Physical Activity Questionnaire for Older Children ( $P A Q-C)$ and Adolescents ( PAQ-A) Manual. (2004).

12. Hardy, L. L., Booth, M. L. \& Okely, A. D. The reliability of the Adolescent Sedentary Activity Questionnaire (ASAQ). Prev. Med. (Baltim). 45, 71-74 (2007).

13. Putra, W. N. Hubungan Pola Makan, Aktivitas Fisik, dan Aktivitas Sedentari dengan Oveweight di SMA Negeri 5 Surabaya. (Universitas Airlangga, 2017).
14. Ermona, N. D. N. \& Wirjatmadi, B. Hubungan Aktivitas Fisik Dan Asupan Gizi Dengan Status Gizi Lebih Pada Anak Usia Sekolah Dasar Di Sdn Ketabang 1 Kota Surabaya Tahun 2017. Amerta Nutr. 2, 97-105 (2018).

15. Hendro Bidjuni, Sefti Rompas, M. I. B. Hubungan Pola Makan Dengan Kejadian Obesitas Pada Anak Usia 8-10 Tahun Di SD Katolik 03 Frater Don Bosco Manado. J. keperawatan 2, 1-7 (2014).

16. Marshall, SJ, SJH Biddle, Gorely, T, Cameron, N, Murdey, and I. Relationships between media use, body fatness and physical activity in children and youth: A meta-analysis. Int. J. Obes. 28, $1238-1246$ (2004).

17. Almatsier, S. Prinsip Dasar Ilmu Gizi. (PT Gramedia Pustaka Utama, 2003).

18. Kreuser, F. \& K. Kromeyer- Hauschild, A. Gollhofer, U. Korsten-Reck, K. R. Analysis of the Association between Weight Status and Physical Activity in Children. J. Obes. 8 (2013).

19. Mejbah Uddin Bhuiyan, S. Z. \& T. A. Risk factors associated with overweight and obesity among urban school children and adolescents in Bangladesh: a case-control study. BMC Pediatr. 13, 72 (2013).

20. Angel Lolita Danari, Nelly Mayulu, F. O. Hubungan Aktivitas Fisik Dengan Kejadian Obesitas Pada Anak Sd Di Kota Manado. ejournal keperawatan 1, 4-7 (2013).

21. Dencker, M., Thorsson, O., Karlsson, M. K., Lindén, C., Wollmer, P., \& Andersen, L. B. Daily physical activity related to body fat in children aged 8-11 years. J. Pediatr. 1, 38-42 (2006).

22. Miko, A. \& Dina, P. B. Hubungan Pola Makan Pagi dengan Status Gizi pada Mahasiswi Poltekkes Kemenkes Aceh. AcTion Aceh Nutr. J. 1, 83 (2016).

23. Biddle, stuart J.H., natalie Pearson, Gemma M. Ross, R. B. Tracking of sedentary behaviours of young people: A systematic review. Prev. Med. (Baltim). 51, 345-351 (2010).

24. Andi Imam Arundhana, Hamam Hadi, M. J. Perilaku sedentari sebagai faktor risiko kejadian obesitas pada anak sekolah dasar di Kota Yogyakarta dan Kabupaten Bantul. J. Gizi dan Diet. Indones. 1, 71-80 (2013).

25. Shang, L. \& Wang, Jiawei, Jennifer O'Loughlin, Angelo Tremblay, Marie-ève Mathieu, Mélanie Henderson, K. G. Screen time is associated with dietary intake in overweight. Prev. Med. Reports J. 2, 265-269 (2015).

26. Nicolas Stettler, Babette S. Zemel, S. K. \& Stallings, V. A. S. Infant Weight Gain and Childhood Overweight Status in a Multicenter, Cohort Study. Pediatrics 109, (2002). 